\title{
Hydration kinetics, physicochemical composition, and textural changes of transgenic corn kernels of flint, semi-flint, and dent varieties
}

\author{
Barbara Celuppi MARQUES ${ }^{1}$, Luiz Mario de Matos JORGE², Regina Maria Matos JORGE ${ }^{1 \star}$
}

\begin{abstract}
The hydration kinetics of transgenic corn types flint DKB 245PRO, semi-flint DKB 390PRO, and dent DKB 240 PRO was studied at temperatures of $30,40,50$, and $67^{\circ} \mathrm{C}$. The concentrated parameters model was used, and it fits the experimental data well for all three cultivars. The chemical composition of the corn kernels was also evaluated. The corn cultivar influenced the initial rate of absorption and the water equilibrium concentration, and the dent corn absorbed more water than the other cultivars at the four temperatures analyzed. The effect of hydration on the kernel texture was also studied, and it was observed that there was no significant difference in the deformation force required for all three corn types analyzed with longer hydration period.
\end{abstract}

Keywords: diffusion; kinetic model; mass transfer; cereals and grains; chemical composition; physical properties; food properties.

\section{Introduction}

Corn (Zea mays L.) is a good primary starch source, and close to one-fourth of the corn starch produced is sold as modified or unmodified starch products for the food or paper industry; the remainder is processed into hydrolyzed products such as corn syrup and fructose (Yaptenco et al., 1996). Starch can be obtained through a wet milling process, in which the kernels are primarily soaked in a solution containing sulfur dioxide $\left(\mathrm{SO}_{2}\right)$ and lactic acid $\left(\mathrm{C}_{3} \mathrm{H}_{6} \mathrm{O}_{3}\right)$ for 24 to 60 hours. Sulfur dioxide prevents microorganisms from growing and reacts with proteins helping to release starch granules. In addition, lactic acid contributes to the kernel inner softening and increases $\mathrm{SO}_{2}$ diffusion speed (Haros \& Suárez, 1999) and (Lopes Filho et al., 2006).

In the wet-milling process, the grains are steeped at temperatures below starch gelatinization temperature. Ratnayake \& Jackson (2006) studied the behavior of corn starch granules in water solution at different temperatures and found that the total rupture of these granules and consequent formation of a gelatinized solution did not occur at temperatures below $70^{\circ} \mathrm{C}$.

Modeling of mass transfer in kernels during hydration has been thoroughly considered (Turhan et al., 2002). Models used for studying kernel hydration may be empirical as that proposed by Peleg (1988) or phenomenological (Coutinho et al., 2007; Omoto et al., 2007) and (Nicolin et al., 2012).. Peleg model is the most commonly used empirical model to describe grain hydration phenomenon (Botelho et al. (2010) for rice, Botelho et al. (2013) for corn).

Empirical models are built from mathematical correlations of experimental data, while phenomenological models are based on mass transfer laws.

Wet milling process aims to separate corn kernel into its basic components, starch, protein (gluten), germ, and fiber. The main purpose of this process is the maximum possible starch recovery (Lopes Filho, 1999). Therefore, corn is steeped in a heated solution during hydration to soften and help separate its components (Rausch \& Belyea, 2006). Accordingly, this study aims to evaluate hydration kinetics of three corn varieties during hydration process and gather information about the kernel texture changes (hardness) during this process as a function of moisture and temperature.

\section{Materials and methods}

\subsection{Chemical composition}

Moisture content of the samples was determined using the standard AOAC method 925.09 (Association Of Official Analytical Chemists, 1995) on dry basis. Total nitrogen content of the samples was determined by the micro-Kjeldahl method according to the AOAC method 920.87 (Association Of Official Analytical Chemists, 1995). The factor 6.25 was used to convert detected nitrogen into protein. The lipid content of the samples was evaluated by Soxhlet extraction using diethyl ether as solvent, according to the AOAC method 925.09 (Association Of Official Analytical Chemists, 1995). Ash content was determined after sample burning in muffle furnace at $550^{\circ} \mathrm{C}$, following the AOAC method 923.03 (Association Of Official Analytical Chemists, 1995). The carbohydrate content was calculated by difference on dry basis (carbohydrate $\%=100-[$ moisture $\%+$ protein $\%+$ lipid $\%+$ ash $\%])$. The analyses were carried out in triplicate. The chemical composition results of the three cultivars were compared by the Tukey test at $5 \%$ probability.

\subsection{Kernel hydration kinetics}

The experiments were carried out at the Laboratory of the Federal University of Paraná. Samples of the following transgenic corn from the 2012 harvest, flint DKB 245PRO,

\footnotetext{
Received 19 Sept., 2013

Accepted 31 Jan., 2014 (006194)

${ }^{1}$ Setor de Tecnologia, Programa de Pós-graduação em Engenharia de Alimentos, Departamento de Engenharia Química, Centro Politécnico,

Universidade Federal do Paraná - UFPR, Curitiba, PR, Brasil, e-mail: reginacspr@yahoo.com.br

${ }^{2}$ Departamento de Engenharia Química, Universidade Estadual de Maringá - UEM, Maringá, PR, Brasil

${ }^{*}$ Corresponding author
} 
semi-flint DKB 390PRO, and dent DKB 240PRO, were provided by the Agronomic Institute of Paraná (Instituto Agronômico do Paraná) (IAPAR). The samples were washed through a sieve and manually selected to remove small and broken kernels and impurities. Moisture content (wet basis) of the three kernel types at the beginning of experiments was $0.1278,0.1093$, and $0.1128 \mathrm{~g} / \mathrm{g}$ for DKB 240PRO, DKB 390PRO, and DKB 245PRO, respectively.

A thermostatic bath (Dubnoff, Model 304, Nova Ética, Brazil) was used in the present study. The hydration experiments were performed at the temperatures of $30,40,50$, and $67{ }^{\circ} \mathrm{C}$ $+/-1^{\circ} \mathrm{C}$ with agitation of $70 \mathrm{rpm}$.

Samples of $160 \mathrm{~g}$ of corn kernels were placed in $500 \mathrm{ml}$ hermetic flasks with $300 \mathrm{ml}$ of solution containing $0.2 \%$ sulfur dioxide $\left(\mathrm{SO}_{2}\right)$ and $0.55 \%$ lactic acid $\left(\mathrm{C}_{3} \mathrm{H}_{6} \mathrm{O}_{3}\right)$. A solution was obtained by adding $11 \mathrm{ml}$ lactic acid and $5.9 \mathrm{~g}$ sodium metabisulfite in $2000 \mathrm{ml}$ of distilled water, according to procedure proposed by Lopes Filho et al. (2006).

Tests were carried out in duplicate, and sampling was performed during pre-established periods. Then surface water was removed with paper towel, and the samples were subjected to moisture and density analysis. Density analysis was conducted using the water displacement method in a graduated cylinder containing 18 kernels per measurement. The kernel radius was calculated considering it a spherical particle. Moisture content was determined by the oven drying method at $105^{\circ} \mathrm{C}$ until constant weight (Instituto Adolf Lutz, 1985).

Corn mass concentration $\left(\rho_{\mathrm{A}}\right)$ was calculated by multiplying corn density $\left(\rho_{\text {corn }}\right)$ by moisture content on a wet basis $\left(X_{\mathrm{wb}}\right)$, as shown by Equation 1.

$\rho_{A}=X_{w b} \cdot \rho_{\text {corn }}$

Moisture content on a wet basis was calculated according to Equation 2, where $M U$ is kernel weight before drying, and $M S$ is the kernel weight after drying.

$$
X_{w b}=\frac{M U-M S}{M U}
$$

\subsection{Mathematical modeling}

To study corn hydration, the concentrated parameters model proposed by Omoto et al. (2009) was used and is represented by Equation 3. This model is based on transient mass balance inside the grain considering that water concentration inside the kernel is homogeneous, the volume is constant, and its geometry is spherical.

$\frac{d\left(\rho_{A}\right)}{d t}=\frac{3 K_{s}}{r_{0}}\left(\rho_{\text {Aeq }}-\rho_{A}\right)$

Calculating the integral of Equation 3 and considering that both $\rho_{\text {Aeq }}$ and $K_{\mathrm{s}}$ are constant for a given temperature, Equation 4 can be obtained. This model has two adjustable parameters, namely mass transfer coefficient $\left(K_{s}\right)$ and equilibrium mass concentration in the kernel $\left(\rho_{\text {Aeq }}\right)$. $\ln \left(\frac{\rho_{A e q}-\rho_{A}}{\rho_{A e q}-\rho_{A 0}}\right)=-\frac{3 K_{s}}{r_{0}} t$

\subsection{Model fitting}

To evaluate the goodness-of-fit of the model to experimental data, determination coefficients $\left(\mathrm{R}^{2}\right)$, and squared deviation were considered in relation to original data. Squared deviation of the concentrated parameters model was calculated as shown by Equation 5 . The lower the deviation value, the better the representation of the model.

$$
\phi^{2}=\sum_{i=1}^{n} \frac{\left(\rho_{\text {Amod }}^{i}-\rho_{\text {Aexp }}^{i}\right)^{2}}{n}
$$

\subsection{Texture analysis}

Kernel texture (hardness) during hydration was evaluated using a texture analyzer (CT3, manufactured by Brookfield, United States of America). The texture analyzer was calibrated with $2 \mathrm{~kg}$ force (Joshi et al., 2010) and probe of $6 \mathrm{~mm}$ diameter and $35 \mathrm{~mm}$ width. The following parameters were also used: target value of $1.5 \mathrm{~mm}$ and test speed of $2 \mathrm{~mm} / \mathrm{s}$.

Samples of twenty-five corn kernels were removed from the flasks at pre-established periods of hydration, starting at 10 minutes. Afterwards, the samples were dried with paper towel for texture analysis. Hardness of each kernel corresponds to the peak of force-deflection curve generated by the texture analyzer. Kernel orientation was kept constant during the experiments, and deflection was carried out in the central part of the corn endosperm. Reported values are the average of 25 kernels at each experimental time evaluated.

\section{Results and discussions}

\subsection{Physicochemical properties}

The average chemical composition of the three corn varieties is presented in Table 1. Semi-flint corn DKB 390PRO and flint corn DKB 245PRO showed no significant difference in their chemical composition, except for moisture content. With regards to size, flint corn and semi-flint corn had larger radii in relation to that of the dent; DKB 240PRO showed significant difference in moisture, protein, lipids, and carbohydrates content in comparison with the other two types. However, ash content did not vary significantly for these three types of cultivar studied.

\subsection{Hydration kinetics}

Figures 1 shows the hydration isotherm, in which water mass concentration varies during hydration for all three corn types. At the beginning, water absorption is fast and tends to decrease until it reaches equilibrium. In addition, water absorption speed increases as temperature rises. Solid lines in Figures 1 represent the results of the prediction of the mathematical model of concentrated parameters during 
Table 1. Physicochemical properties of the three corn cultivars.

\begin{tabular}{cccc}
\hline Properties & DKB 240PRO & DKB 390PRO & DKB 245PRO \\
\hline Moisture (\%) & $12.9^{\mathrm{a}} \pm 0.01$ & $11.0^{\mathrm{c}} \pm 0.01$ & $11.4^{\mathrm{b}} \pm 0.01$ \\
Protein (\%) & $8.49^{\mathrm{a}} \pm 0.05$ & $7.52^{\mathrm{b}} \pm 0.20$ & $7.62^{\mathrm{b}} \pm 0.13$ \\
Lipid (\%) & $3.48^{\mathrm{b}} \pm 0.05$ & $4.32^{\mathrm{a}} \pm 0.08$ & $4.28^{\mathrm{a}} \pm 0.02$ \\
Ash (\%) & $1.08^{\mathrm{a}} \pm 0.01$ & $1.01^{\mathrm{a}} \pm 0.01$ & $1.08^{\mathrm{a}} \pm 0.06$ \\
Carbohydrates (\%) & $74.0^{\mathrm{b}} \pm 0.06$ & $76.1^{\mathrm{a}} \pm 0.14$ & $75.6^{\mathrm{a}} \pm 0.10$ \\
Color & Yellow & Yellow Orange & Orange \\
Kernel type & Dent & Semi-flint & Flint \\
Initial radius (cm) & $0.39^{\mathrm{b}} \pm 0.01$ & $0.40^{\mathrm{a}} \pm 0.01$ & $0.40^{\mathrm{a}} \pm 0.01$ \\
\hline
\end{tabular}

$\mathrm{a}, \mathrm{b}, \mathrm{c}-$ Means in the same row followed by the same subscript letter do not show significant difference $(\mathrm{p}<0.05)$. Carbohydrate $\%=100-(\mathrm{moisture} \%+$ protein $\%+$ lipid $\%+$ ash $\%)$.
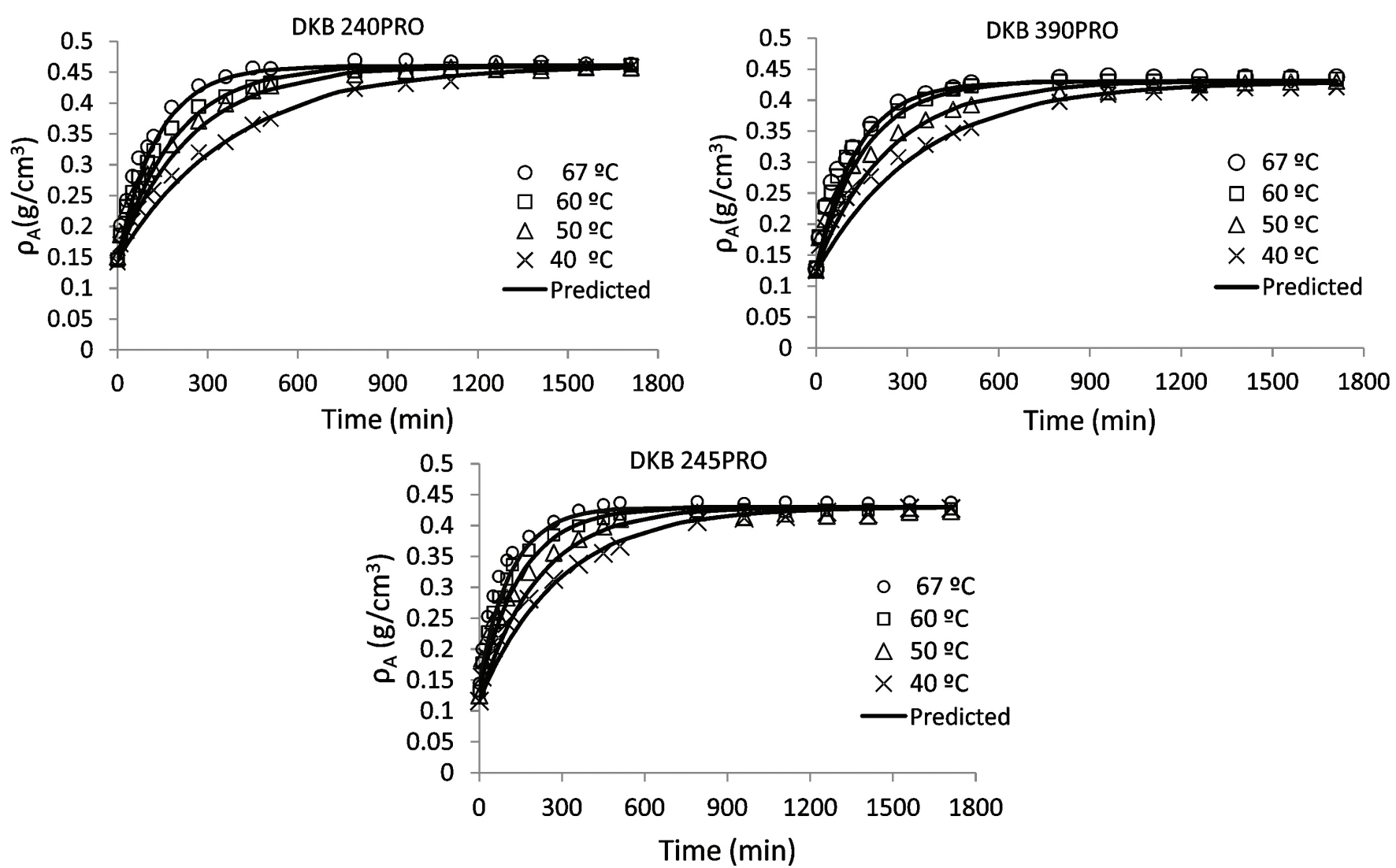

Figure 1. Model predictions and experimental data for hydration of three corn cultivars: dent DKB 240PRO, semi-flint KB 390PRO, and flint DKB 245PRO at four soaking temperatures.

hydration. On average, the model fits the experimental data well, with a maximum mean deviation of 0.00071 .

Table 2 shows the values of equilibrium mass concentration $\left(\rho_{\text {Aeq }}\right)$ obtained experimentally for each hybrid and soaking temperature. Temperature did not significantly affect the amount of water absorbed by each cultivar. Mean equilibrium mass concentrations of dent, semi-flint, and flint corns were $0.4615,0.4311$, and $0.4340 \mathrm{~g} / \mathrm{cm}^{3}$, respectively. Protein is the major component absorbing water in the kernel although other chemical components also contribute to this phenomenon. In addition, smaller kernels may absorb more water due to the increased surface area for absorption. On the other hand, fat content is the main component that may limit absorption (Sopade \& Obekpa, 1990; Sopade et al., 1992), and (Joshi et al.,
Table 2. Values of equilibrium mass concentration found for all three types of corn at different temperatures.

\begin{tabular}{cccc}
\hline $\begin{array}{c}\text { Temperature } \\
\left({ }^{\circ} \mathrm{C}\right)\end{array}$ & $\begin{array}{c}\text { DKB 240PRO } \\
\rho_{\text {Aeq }}\left(\mathrm{g} / \mathrm{cm}^{3}\right)\end{array}$ & $\begin{array}{c}\text { DKB 390PRO } \\
\rho_{\text {Aeq }}\left(\mathrm{g} / \mathrm{cm}^{3}\right)\end{array}$ & $\begin{array}{c}\text { DKB 245PRO } \\
\rho_{\text {Aeq }}\left(\mathrm{g} / \mathrm{cm}^{3}\right)\end{array}$ \\
\hline 40 & $0.4627 \pm 0.0021$ & $0.4219 \pm 0.0001$ & $0.4309 \pm 0.0043$ \\
50 & $0.4610 \pm 0.0031$ & $0.4321 \pm 0.0004$ & $0.4312 \pm 0.0006$ \\
60 & $0.4610 \pm 0.0020$ & $0.4336 \pm 0.0051$ & $0.4320 \pm 0.0001$ \\
67 & $0.4613 \pm 0.0001$ & $0.4371 \pm 0.0012$ & $0.4420 \pm 0.0021$ \\
\hline
\end{tabular}

2010). Therefore, the higher capacity of water absorption of dent corn may be a result of higher protein content, lower amount of lipids, and carbohydrates. According to Sopade et al. (1992), the higher protein content, lower carbohydrates, and fat content 
present in sorghum grains in comparison with those of the millet have also been appointed as possible factors for the higher absorption capacity by sorghum. Sopade \& Obekpa (1990) reported that the smaller the seed, the larger its water absorption capacity because of larger surface area available for absorption. This fact was also observed for dent corn DKB 240PRO, which was the smaller and absorbed more water.

Dent corn DKB 240PRO showed higher amount of water absorbed at temperatures from 40 to $67{ }^{\circ} \mathrm{C}$, with significant difference from the other grains $(\mathrm{p}<0.05)$.

Equation 4 was fitted to hydration experimental data at each temperature to obtain $K_{\mathrm{s}}$ parameter (diffusion coefficient) by linear regression, as shown in Figure 2. Therefore, the mean equilibrium mass concentration obtained experimentally for each cultivar was used: $0.4615,0.4311$, and $0.4340 \mathrm{~g} / \mathrm{cm}^{3}$ for dent corn DKB 240PRO, semi-flint corn DKB 390PRO, and flint corn DKB 245PRO, respectively.

Diffusion coefficients $\left(K_{\mathrm{s}}\right)$ obtained at the four temperatures for the three corn cultivars with their respective determination coefficients are presented in Table $3 . \mathrm{R}^{2}$ values ranged from 0.969 to 0.996 , indicating good fit to obtain $K_{\mathrm{s}}$ parameters.

Dent corn showed lower diffusion coefficient value and had higher water equilibrium concentration than the other grains at the four temperatures analyzed. Figure 3 shows the hydration isotherms of dent and flint corn at $67^{\circ} \mathrm{C}$. At the beginning of the process, from 30 to 120 minutes, dent corn DKB 240PRO showed low absorption rate. After this period, its water content increased more rapidly than that of the flint corn DKB 245PRO. Protein may be the main factor responsible for this behavior. Dent corn contains higher amount of protein in its composition when compared to that of the other cultivars, which can indicate

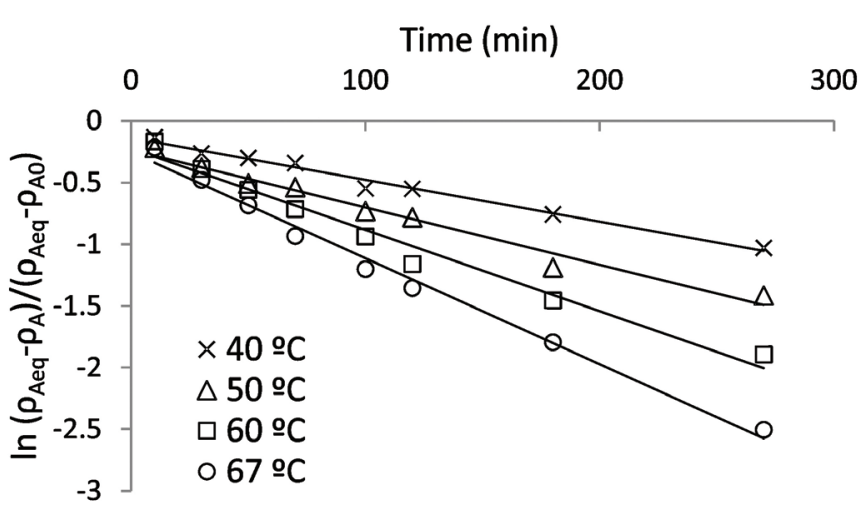

Figure 2. Mathematical model fitting for flint corn DKB 245PRO. a more compact endosperm and therefore greater difficulty to diffusing through water. However, protein content and the smaller size of the dent grain might have contributed to a larger water absorption capacity of this kernel after 120 minutes.

\subsection{Determining activation energy}

The relationship between mass transfer coefficient $\left(K_{\mathrm{s}}\right)$ and temperature can be represented by the Arrhenius equation, which is shown in its linear form in Equation 6. In Figure 4, it is possible to observe that the equation properly represented temperature effect on diffusion coefficient, with determination coefficients varying from 0.9943 to 0.9987 . After calculating parameter $E^{\prime}$ by linear regression, activation energy was determined, with values of $34.07,31.96$, and $31.95 \mathrm{KJ} / \mathrm{mol}$ for dent corn DKB 240PRO, semi-flint corn DKB 390PRO, and flint corn DKB 245PRO, respectively. This fact indicates

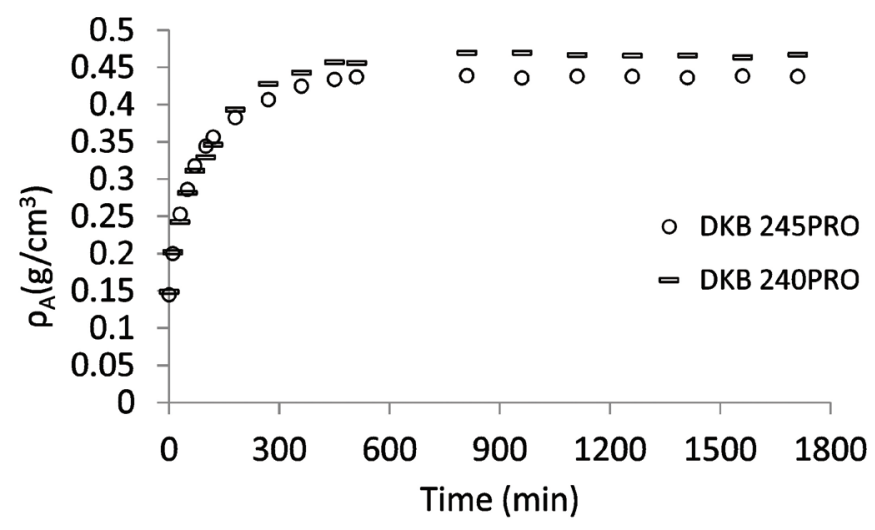

Figure 3. Hydration isotherms of DKB 240PRO and DKB 245PRO at $67^{\circ} \mathrm{C}$.

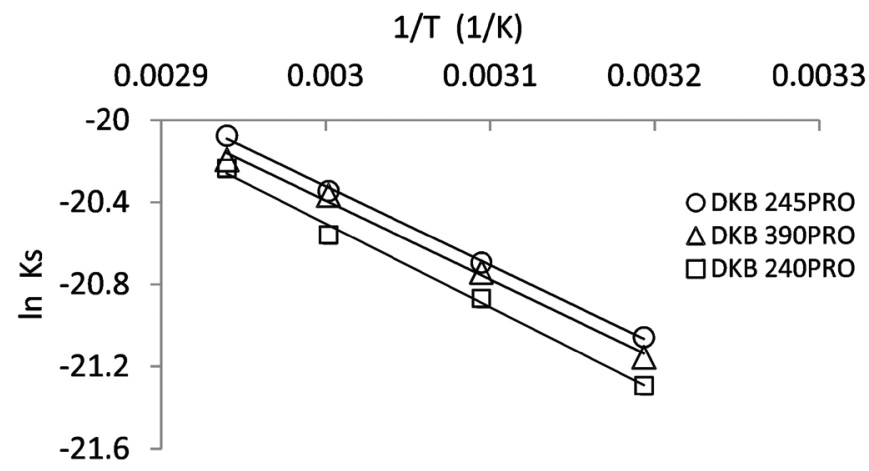

Figure 4. Fitting Arrhenius Equation for the effect of temperature on diffusion coefficient $\left(\mathrm{K}_{\mathrm{s}}\right)$ for the corn cultivars: DKB 240PRO, DKB 390PRO, and DKB 245PRO.

Table 3. Values of $K_{\mathrm{s}}$ parameters and their respective determination coefficients $\left(\mathrm{R}^{2}\right)$ for the three kernels cultivars at four soaking temperatures.

\begin{tabular}{|c|c|c|c|c|c|c|}
\hline \multirow{2}{*}{$\begin{array}{c}\text { Temperature } \\
\left({ }^{\circ} \mathrm{C}\right)\end{array}$} & \multicolumn{2}{|c|}{ DKB 240PRO } & \multicolumn{2}{|c|}{ DKB 390PRO } & \multicolumn{2}{|c|}{ DKB 245PRO } \\
\hline & $K_{\mathrm{s}}\left(\mathrm{m}^{2} / \mathrm{s}\right)$ & $\mathrm{R}^{2}$ & $K_{\mathrm{s}}\left(\mathrm{m}^{2} / \mathrm{s}\right)$ & $\mathrm{R}^{2}$ & $K_{\mathrm{s}}\left(\mathrm{m}^{2} / \mathrm{s}\right)$ & $\mathrm{R}^{2}$ \\
\hline 40 & $5.66 \times 10^{-10}$ & 0.969 & $6.50 \times 10^{-10}$ & 0.981 & $7.16 \times 10^{-10}$ & 0.986 \\
\hline 60 & $11.8 \times 10^{-10}$ & 0.994 & $14.3 \times 10^{-10}$ & 0.989 & $14.6 \times 10^{-10}$ & 0.976 \\
\hline 67 & $16.5 \times 10^{-10}$ & 0.996 & $17.0 \times 10^{-10}$ & 0.991 & $19.1 \times 10^{-10}$ & 0.989 \\
\hline
\end{tabular}




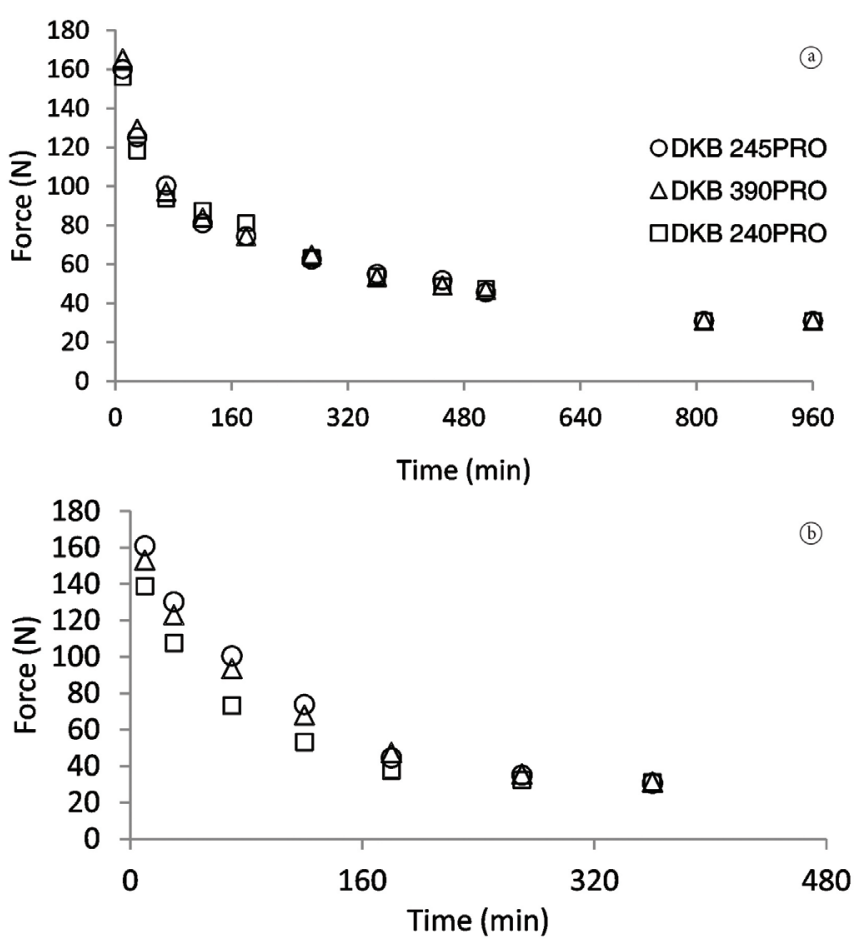

Figure 5. Texture of the three corn types at soaking temperatures of (a) $40{ }^{\circ} \mathrm{C}$ and (b) $67^{\circ} \mathrm{C}$.

that the corn cultivars DKB 245PRO (flint) and DKB 390PRO (semi-flint) were less affected by the soaking temperature. The activation energy values found are similar to that obtained by Lopes Filho et al. (2006), who reported a value of $33.8 \mathrm{~kJ} / \mathrm{mol}$ for hybrid corn (zêneca 8392).

$\ln \left(\mathrm{K}_{\mathrm{s}}\right)=\ln \left(\mathrm{K}_{0}\right)-\mathrm{E}^{\prime} \cdot \frac{1}{\mathrm{~T}}$

\subsection{Analysis of corn texture during hydration}

Texture analysis of the corn cultivars DKB 245PRO, DKB $390 \mathrm{PRO}$, and $\mathrm{DKB} 240 \mathrm{PRO}$ at temperatures ranging from 40 to $67^{\circ} \mathrm{C}$ is shown in Figure 5. At the temperature of $40{ }^{\circ} \mathrm{C}$ (Figure 5a), all three cultivars showed no significant difference in texture reduction during hydration.

With temperature rise from $40{ }^{\circ} \mathrm{C}$ to $67^{\circ} \mathrm{C}$ (Figure 5b), flint and semi-flint corns differed in texture as compared to dent corn at the beginning of the experimental process. However, this difference decreased during hydration, and no significant difference was observed between the three cultivars after $270 \mathrm{~min}$. At this temperature, incomplete gelatinization of starch may have occurred. The gelatinized starch creates a continuous matrix of amorphous starch, while native starch is a discontinuity that acts as weak points where fracture is more likely to occur (Karkle et al., 2012). Dent corn seems to require lower deforming force early in the process, due to presence of more regions of weak point, compared with the other two corns.

As water is distributed in the grain, the required force decreases until it reaches an equilibrium value (Abu-Ghannam,
1998). Deformation force required for all three corn types decreased up to $31 \pm 0.6 \mathrm{~N}$ after a certain period of hydration at these two temperatures.

\section{Conclusions}

Kernel type affected water absorption, and dent corn DKB 240PRO absorbed more water than the other two cultivars studied, which indicates the need for different process control for this grain. Such difference may be related to the kernel type, chemical composition, and growing conditions.

Diffusion coefficients $\left(K_{\mathrm{s}}\right)$ values of all three varieties of corn increased with temperature rise, thus indicating that hydration speed is faster as temperature increases. $K_{\mathrm{s}}$ dependence on temperature was well described by the Arrhenius equation, showing activation energy values of $34.07,31.96$, and $31.95 \mathrm{KJ} /$ mol for dent corn DKB 240PRO, semi-flint corn DKB 390PRO, and flint corn DKB 245PRO respectively.

With longer period of hydration, the three varieties showed no significant difference in kernel hardness at temperatures of $40^{\circ} \mathrm{C}$ and $67^{\circ} \mathrm{C}$. The final deformation force required by all three corn types was not affected by hydration temperature.

The model of concentrated Parameters fits well to the experimental data obtained during hydration of the three corn kernel cultivars at the temperatures studied, with a maximum deviation of 0.00071 . This model can be a useful tool for process design, optimization and product development.

\section{Acknowledgements}

The authors would like to thank IAPAR (Brazil) for the donation of corn grains, and CAPES (Brazil) for the scholarship granted to the first author. The authors declare that there are no conflicts of interest.

\section{Nomenclature}

\begin{tabular}{|c|c|c|}
\hline$K_{0}$ & Arrhenius equation pre-exponential parameter & $\left(\mathrm{m}^{2} / \mathrm{s}\right)$ \\
\hline$E^{\prime}$ & Arrhenius equation parameter & $(1 / \mathrm{K})$ \\
\hline$\Phi^{2}$ & Squared deviation & (dimensionless) \\
\hline$K_{\mathrm{s}}$ & Apparent mass transfer coefficient & $\left(\mathrm{m}^{2} / \mathrm{s}\right)$ \\
\hline$M S$ & Kernel dry weight & (g) \\
\hline$M U$ & Kernel moisture weight & (g) \\
\hline$r_{\mathrm{o}}$ & Kernel Initial Radius & $(\mathrm{cm})$ \\
\hline$T$ & Temperature & $\left({ }^{\circ} \mathrm{C}\right)$ \\
\hline$t$ & Time & $(\min )$ \\
\hline$X_{\mathrm{wb}}$ & Moisture on wet basis & $(\mathrm{g} / \mathrm{g})$ \\
\hline$\rho_{\mathrm{A}}$ & Water mass concentration of the kernel & $\left(\mathrm{g} / \mathrm{cm}^{3}\right)$ \\
\hline$\rho_{\mathrm{Ao}}$ & Initial water mass concentration of the kernel & $\left(\mathrm{g} / \mathrm{cm}^{3}\right)$ \\
\hline$\rho_{\text {Aeq }}$ & $\begin{array}{l}\text { Water equilibrium mass concentration of the } \\
\text { kernel }\end{array}$ & $\left(\mathrm{g} / \mathrm{cm}^{3}\right)$ \\
\hline$\rho_{\text {Aexp }}$ & $\begin{array}{l}\text { Water mass concentration experimental of the } \\
\text { kernel }\end{array}$ & $\left(\mathrm{g} / \mathrm{cm}^{3}\right)$ \\
\hline$\rho_{\text {Amod }}$ & $\begin{array}{l}\text { Water mass concentration of the kernel } \\
\text { calculated by the model }\end{array}$ & $\left(\mathrm{g} / \mathrm{cm}^{3}\right)$ \\
\hline$\rho_{\text {corn }}$ & Kernel density & $\left(\mathrm{g} / \mathrm{cm}^{3}\right)$ \\
\hline
\end{tabular}




\section{References}

Abu-Ghannam, N. (1998). Modelling textural changes during the hydration process of red beans. Journal of Food Engineering, 38(3), 341-352. http://dx.doi.org/10.1016/S0260-8774(98)00127-7

Association Of Official Analytical Chemists - AOAC. (1995). Official methods of analysis of the Association of Official Analytical Chemists (cap. 39, pp. 21). Arlington: AOAC. (Method 958.06).

Botelho, F. M., Corrêa, P. C., Goneli, A. L. D., Martins, M. A., \& Baptestin, F. M. (2010). Análise da hidratação do arroz na parboilização. Ciência e Tecnologia de Alimentos, 30(3), 713-718. http://dx.doi.org/10.1590/S0101-20612010000300023

Botelho, F. M., Corrêa, P. C., Martins, M. A., Botelho, S. C. C., \& Oliveira, G. H. H. (2013). Effects of the mechanical damage on the water absorption process by corn kernel. Food Science and Technology, 33(2), 282-288.

Coutinho, M. R., Conceição, W. A. S., Omoto, E. S., Andrade, C. M. G., \& Jorge, L. M. M. (2007). Novo modelo de parâmetros concentrados aplicado à hidratação de grãos. Ciência e Tecnologia de Alimentos, 27(3), 451-455. http://dx.doi.org/10.1590/S010120612007000300005

Haros, M., \& Suárez, C. (1999). Effect of chemical pretreatments and lactic acid on the rate of water absorption and starch Yield in corn wet-milling. Cereal Chemistry, 76(5), 783-787. http://dx.doi. org/10.1094/CCHEM.1999.76.5.783

Instituto Adolf Lutz - IAL. (1985). Normas analíticas do Instituto Adolf Lutz (3. ed.). São Paulo: IAL.

Joshi, M., Adhikari, B., Panozzo, J., \& Aldred, P. (2010). Water uptake and its impact on the texture of lentils (Lens culinaris). Journal of Food Engineering, 100(1), 61-69. http://dx.doi.org/10.1016/j. jfoodeng.2010.03.028

Karkle, E. L., Keller, L., Dogan, H., \& Alavi, S. (2010). Matrix transformation in fiber-added extruded products: impact of different hydration regimens on texture, microstructure and digestibility. Journal of Food Engineering, 108, (1), 171-182. http:// dx.doi.org/10.1016/j.jfoodeng.2011.06.020

Lopes Filho, J. F. (1999). Avaliação da maceração dinâmica do milho após um curto período de hidratação e subsequente quebra do pericarpo do grão. Ciência e Tecnologia de Alimentos, 19(3), 322-325. http://dx.doi.org/10.1590/S0101-20611999000300005
Lopes Filho, J. F., Ramos, A. P., \& Romero, J. T. (2006). Difusividades da água, dióxido de enxofre e ácido lático em grãos de milho durante a maceração para o processo de moagem úmida. Brazilian Journal of Food Technology, 9(4), 257-263.

Nicolin, D. J., Coutinho, M. R., Andrade, C. M. G., \& Jorge, L. M. M. (2012). Hsu model analysis considering grain volume variation during soybean hydration. Journal of Food Engineering, 111(3), 496- 504. http://dx.doi.org/10.1016/j.jfoodeng.2012.02.035

Omoto, E. S., Andrade, C. M. G., Jorge, R. M. M., Coutinho, M. R., Paraíso, P. R., \& Jorge, L. M. M. (2009). Modelagem matemática e análise da hidratação de grãos de ervilha. Ciência e Tecnologia de Alimentos, 29(1), 12-18. http://dx.doi.org/10.1590/S010120612009000100003

Peleg, M. (1988). An empirical model for the description of moisture sorption curves. Journal of Food Science, 53(4), 1216-1219. http:// dx.doi.org/10.1111/j.1365-2621.1988.tb13565.x

Ratnayake, W. S., \& Jackson, D. S. (2006). Gelatinization and solubility of corn starch during heating in excess water: new insights. Journal of Agricultural and Food Chemistry, 54(10), 3712-3716. PMid:19127749. http://dx.doi.org/10.1021/jf0529114

Rausch, K. D., \& Belyea, R. L. (2006). The future of coproducts from corn processing. Applied Biochemistry and Biotechnology, 128(1), 47-86 http://dx.doi.org/10.1385/ABAB:128:1:047

Sopade, P. A., \& Obekpa, J. A. (1990). Modelling water absorption in soybean, cowpea and peanuts at three temperatures using Peleg's equation. Journal of Food Science, 55(4), 1084-1087. http://dx.doi. org/10.1111/j.1365-2621.1990.tb01604.x

Sopade, P. A., Ajisegiri, E. S., \& Badau, M. H. (1992). The use of Peleg's equation to model water absorption in some cereal grains during soaking. Journal of Food Engineering, 15(4), 269-283. http://dx.doi. org/10.1016/0260-8774(92)90010-4

Turhan, M., Sayar, S., \& Gunasekaran, S. (2002). Application of Peleg model to study water absorption in chickpea during soaking. Journal of Food Engineering, 53(2), 153-159. http://dx.doi.org/10.1016/ S0260-8774(01)00152-2

Yaptenco, K. F., Fox, E. J., \& Eckhoff, S. R. (1996). A laboratory countercurrent steep battery for corn wet-milling. Cereal Chemistry, 73(2), 249-256. 